\title{
Bone mineral density: review
}

\section{Author(s)}

Almeida Paz ICL

Bruno LDG²

Post-doctorate student of the Department of Animal Production of the School of Veterinary Medicine and Animal Science, UNESP/Botucatu, SP

2 Post-doctorate student of the Department of Animal Science of the Center of Agrarian Sciences, UEM/Maringá, PR

\section{Mail Address}

ICL Almeida Paz

Faculdade de Medicina Veterinária e Zootecnia - UNESP

Fazenda Experimental Lageado, $s / n^{\circ}$

Depto de Produção e Exploração Animal

18.618-000. Botucatu, SP, Brasil

E-mail: ibiara@fca.unesp.br

LDG Bruno

Centro de Ciências Agrárias

Avenida Colombo, 5790

Departamento de Zootecnia

87.020-900. Maringá, PR, Brasil

E-mail: Idgbruno@uem.br

\section{- Keywords}

Bone mineral density, bone quality, densitometry and poultry.

\section{Bones}

Bone mineral density is one of the most important factors to measure bone quality. It is a biophysical parameter of critical experimental importance, and has been used in poultry production as a tool to assess bone quality because it is a reliable and non-invasive method.

Bones have an essential role in normal growth and development of vertebrate individuals. Its development process is a complex sequence of interrelated events in space and time, leading to bone formation. There are two processes of bone development: intramembranous bone formation, and endochondral bone formation. Cell mechanisms are identical in both process, with intramembranous bone formation being responsible for the definitive shape of a limited number of bones which are not pre-formed by cartilage. Endochondral bone formation involves the activities responsible for the formation of bones that bear weight, which also are responsible for the elongation of most skeletal mass during growth. The continuous addition of cartilage and its later replacement by bone are the essence of the process of elongation (Howlet, 1980; Banks, 1991; Thorp, 1992; Almeida Paz et al., 2005).

\section{Bone mineral density}

Bone tissue rigidity results from the deposition of calcium and phosphorus as hydroxiapatite during bone mineralization process. Both minerals make up about $70 \%$ of the bone composition; the remaining $30 \%$ consist of organic matter, mainly of collagen (Kälebo \& Strid, 1988a; Field, 1999; Bruno, 2002). Hydroxyapatite and aluminum have similar density, and thus many authors conducted studies aiming at relating bone mineralization degree with aluminum density, and concluded that it is possible to compare, using radiological study, the amount of calcium and phosphorus deposited in the bones to the amount of aluminum found in a pre-determined scale (Lobel \& Dubois, 1973; Kälebo \& Strid, 1988a; Kälebo \& Strid, 1988b). this technique for determining bone mineralization degree is called Optical Densitometry in Radiographic Images.

This technique is an area of Sensitometry, which studies the photochemical action of light on sensitive emulsions, providing a means to measure this action, and to determine the relation between the amount of light received by a sensitive film and the amount of silver salt that will be reduced by direct blackening or by a developer (Louzada, 1994, Garton et al. (1994) e Louzada (1997). In addition, this technique can replace the bone density determined using a photodensitometer, which is conventionally used (Tavano et al., 2000).

Bone mineral density can also be measured using bone mineral composition, bone breaking strength, and Seedor index (Seedor, 1995), among others (Orban et al., 1983). In an experiment with White Leghorn 
chickens, Zhang \& Coon (1997) found that breaking strength, also called bone strength, is not a function of bone ash percentage, but rather a function of bone volume. Bone volume is taking into consideration in the Seedor index. Therefore, these measures are very important when measuring bone quality as they are closely related.

\section{Bone mineral density: influences}

Some factors can directly or indirectly influence bone tissue development in poultry, and thus, its density.

As with other tissues that compose living beings, bone development is closely linked to two main factors: genetic expression of the proteins responsible for body development, and nutritional supply that poultry receive in their diets. Balanced diets will supply nutrients in the adequate amounts to promote the proper development of the entire body, including the bone tissue.

In general, bone tissue development - including its density - is affected by several factors that can be divided in two categories: endogenous factors inherent to the animal itself, and exogenous factors, which do not depend on the animal itself (Bruno, 2002).

Endogenous factors are mainly represented by hormones (parathyroid hormone, growth hormone, IGF-I and II, dihydroxi-vitamin $\mathrm{D}_{3}$ calcitonin, retinoids and interleukins, etc. (Burwell, 1986; Price \& Russel, 1992, Watkins, 1999). It must be noted that dietary energy, which can be considered as the fuel that regulates body development as a whole, including hormone activity, is indirectly linked to bone tissue development.

Among the endogenous factors, genetics has not been much studied as an influence on bone development. It is well-known that modern broiler lines were primarily improved to increase feed intake, which lead to a higher capacity of muscle deposition. This promoted a higher weight load on the bone system, which may have contributed to an increase in the incidence of bone abnormalities. Aiming at evaluating the influence of genetics on bone radiographic density (as well as on other parameters of bone growth, studies performed in our laboratory studied bone development of 3 different genetic groups, characterized by different growth rates. The results showed that the genetic selection imposed to birds did not change the developmental pattern of the density of the long bones of broilers. Bone development rate changes as a function of the different genetic traits of each group, but developmental pattern is exactly the same. This lead us to think that, regardless the genetic selection processes to which the birds are submitted, bone development as a whole, including bone mineral density, has a predetermined pattern of genetic expression, which is manifested with no changes. This is consistent with the fact that bone tissue development is a priority when animal tissues are formed.

Another aspect that is correlated with bone mineralization process, and therefore, with density, is the activity load or physical stimulation to which the birds are submitted. Experiments were carried out to assess higher demand of physical activity on bone tissue development (Bizeray et al., 2000) For instance, Fleming et al. (1994) verified that birds raised on battery cages had lower mineral density values as compared to those raised on litter, demonstrating that the environment may influence bone tissue quality.

\section{Bone densitometry applications}

Some disease, such as osteoporosis, osteopenia, and osteochondrosis were studied using bone densitometry measurement technique in dogs, rabbits, cattle, horses, and humans (Louzada et al., 1990; Garton et al., 1994; Jeffcott \& Henson, 1998, Bourrin et al., 2002; Huang et al., 2002; Kastl et al., 2002), but here are few studies on poultry.

According to Whithead \& Fleming (2000), osteoporosis is a physiological condition in which bones become less dense, more porous, and more susceptible to fractures (incidence increases in 30\%). In commercial layers, which are housed in cages, this bone condition is favored by the accelerated bone development and sexual maturity due to genetic selection for higher production and to calcium sequestration for egg production. Julian (1998), in a study on problems related to rapid development of broilers, found a higher incidence of bone problems, such as deformities, defects, and porosity in birds select for rapid growth.

Louzada (1997) carried out a study using broilers as a model for methodology standardization and clinical application of optical densitometry in radiographic images, and reported that the efficiency of this densitometric technique is evidenced when mean values expressed in aluminum millimeters are compared to calcium percentage means of bone specimens.

When studying tibial dyschondroplasia in broilers using optical densitometry in radiographic images, Almeida Paz et al. (2004) found a relation between densitometry values and the incidence of this disease. 
The increase in optical densitometry in radiographic images corresponded to an increase in the severity of the lesions. This occurred because the lesion boundary regions are characterized by bone sclerosis, which increases BMD of the studied bone structure. According to Pharr \& Bargai (1997) e Cruess \& Dumont (1985), bone regions with lesions may have higher radiodensity due to new bone deposition or to mineralization of dead osteocytes, thereby presenting high bone mineral density values. Crespo et al. (2002), microscopically evaluating and following-up ashes, calcium, phosphorus, manganese, and zinc content in the femura of male and female turkey with or without fractures, concluded that there is higher mineral concentration and formation of calluses in the fractures, which results in higher radiographic density at the site of the lesion.

In the experiment carried out by Onyango et al. (2003), the author evaluated bone densitometry as an indication of bone ash percentage in the tibiae of broilers. They used diets containing different calcium and phosphorus levels, and concluded that the best indication of bone ashes is bone resistance, and that bone mineral density presents a correlation of $86 \%$ with ashes percentage, being therefore a good indication.

Hester et al. (2004) found an increase in bone mineral density in the tibiae of 15- to 25-week-old Leghorn hens. When these birds were submitted to fasting for 10 days, bone mineral density decreased. In a study performed by Schreiweis et al. (2003), the authors assessed bone mineral density of the tíbia and the umerus of white Leghorn hens fed diets with different calcium levels (hypercalcemic 5.4\%, recommended calcium 3.6\%, and hypocalcemic 1.8\%), and concluded that bone mineral density follows a negative linear trend as dietary calcium is reduced. When assessing bone resistance of the fêmur and the umerus of brown and white Leghorn hens at the end of the production cycle (65 weeks of age), Korver et al. (2004) found higher bone resistance in brown hens, probably because these are heavier than the white hens.

\section{Calcium and its influence on bone mineral density}

Calcium requirements of broiler breeders is very high, particularly during the active period of eggshell formation. Calcium used for this purpose derives directly from the diet and indirectly from the medullar bone through a process of bone resorption (Kienholz et al., 1961; Landauer, 1967; Wilson et al., 1980; Wilson, 1983; Luquetti et al., 2002; Julian, 2005). The proportion of calcium derived from these two sources varied according to the period of the day, during the night, when dietary calcium sources are not available, the bird mobilizes calcium from the bones, whereas during the day, most calcium comes from the diet. It is wellknown that the higher the contribution of calcium from the skeleton for eggshell formation, the worst is the eggshell quality.

Literature review shows that bone mineral density values are affected by many factors, such as age, sex, type of production, diet, and management. In broiler breeders reared under dark house systems and fed balanced diets, tibial and femural bone mineral density are influenced by age (increases with age), weight, and egg production. They usually deposit bone minerals during the period preceding the beginning of lay, and bone mineral density decreases as egg production increases. According to Almeida Paz et al. (2006), femura suffer more changes in bone mineral density during lay in broiler breeders, which suggests that this bone is able to provide calcium more easily for maintaining mineral homeostasis. However, when bird requirement increases, the tibia is the main bone supplying this requirement.

According to Julian (2005), the femur of layers is the main bone responsible for calcium supply for eggshell formation. When dietary calcium is not available, the femura of these birds are fragile, porous, and with thin walls. In this circumstance, birds start to remove calcium from the medullar bones, which may lead to death. According to Maggioni (1998), the use of bone calcium for eggshell formation occurs when the calcium available in the diet does not supply the bird's needs.

Calcium deficiency leads to an incomplete calcification of the produced organic matrix. This deficiency may also be due to lack of calcium in the feed oro of pro-vitamin-D hormone, which is important for the absorption of $\mathrm{Ca}^{2+}$ and $\left(\mathrm{PO}_{4}\right)^{3+}$ ions by the small intestine (Junqueira \& Carneiro, 2004).

Some authors studied bone mineral density in birds, and found very different results, demonstrating the influence of many factors on this characteristic. In a study carried out by Almeida Paz et al. (2004), BMO value found in the tibiae of 42-day-old male broilers varied between 1.46 and $1.77 \mathrm{~mm} \mathrm{Al}$, whereas Louzada (1997), studying the same parameter in 53-day-old broiler, found 1.77 and $1.96 \mathrm{~mm}$ Al. In an experiment 
carried out by Oliveira et al. (2005), bone density values found for the tibiae of 42-day-old broilers were 2.47 and $3.50 \mathrm{~mm}$ de Al. Araújo et al. (2004) performed a trial with layers during the second egg production cycle using different dietary sodium levels, and obtained tibial bone density values of 4.0 and $81 \mathrm{~mm}$ de Al.

\section{REFERENCES}

Almeida Paz ICL, Mendes AA, Takita TS, Vulcano LC, Guerra PC, Wescheler FS, Garcia RG. Tibial dyschondroplasia and bone mineral density. Brazilian Journal of Poultry Science 2004; 6:207-12.

Almeida Paz ICL, Mendes AA, Takita TS, Vulcano LC, Guerra PC, Garcia RG. Comparision of Tecnhiques for tibial dyscondroplasia assessment in broilers chickens. Brazilian Journal of Poultry Science 2005; 7:1:27-32.

Almeida Paz ICL. Avaliação da bone mineral density em matrizes pesadas por meio da técnica de densitometria óptica em imagens radiográficas [tese]. Botucatu: Universidade Estadual Paulista; 2006.

Araújo CSS, Baraldi-Artoni SM, Araújo LF, Junqueira OM, Laurentiz AC, Betioli MML. Densidade óssea em poedeiras comerciais no $2^{\circ}$ ciclo de produção. In: Conferência Apinco 2004 de Ciência e Tecnologia Avícolas; 2004; Santos, São Paulo. Brasil. p.139.

Banks WJ. Histologia veterinária aplicada. 2 ed. São Paulo: Editora Manole; 1991, 629 p.

Bizeray D, Leterrier C, Constantin P. et al. Early locomotor behaviour in genetic stocks of chickens with different growth rates. Applied Animal Behaviour Science 2000, 68:231-242.

Bourrin S, Ammann P, Bonjour JP, Rizzoli R. Recovery of proximal tibia bone mineral density and strength, but not cancellous bone architecture, after long-term bisphosphonate or selective estrogen receptor modulator therapy in aged rats. Bone 2002; 30(1):195200.

Bruno LDG. Desenvolvimento ósseo em frangos de corte: Influência da restrição alimentar e da temperatura ambiente [dissertação]. Jaboticabal: Faculdade de Ciências Agrárias e Veterinárias, Universidade Estadual Paulista; 2002.

Crespo R, Stover SM, Shiavaprasad HL, Chin RP. Microstruture and mineral content of femoral in male turkeys with and without factures. Poultry Science 2002; 81:1184-1190.

Cruess RL, Dumont J. Healing of Bone. In: Newton CD, Nunamaker DM, editor. Textbook of small animal orthopaedics. Philadelphia: J.B. Lippincott Company; 1985. p. 35-63.

Fleming RH. et al. Bone structure and breaking strength in laying hens housed in different husbandry systems. British Poultry Science 1994; 35:351:662.

Field RA. Ash and calcium as measures of bone in meat and bone mistures. Meat Science 1999; 55:255-264.
Garton MJ, Robertson EM, Gilbert FJ. et al. Can Radiologists detect osteopenia on plain radiographs? Clinical Radiology 1994; 49:118122.

Hester PY, Schreiweis MA, Orban Jl. et al. Assessing bone mineral density in vivo: dual energy $\mathrm{X}$-ray absorptiometry. Poultry Science 2004; 83:215-221.

Howlet CR. The fine structure of the proximal growth plate metaphysis of the avian tibia: endochondral osteogenesis. Journal of Anatomy 1980; 130:745-768.

Huang Th, Yang RS, Hsieh SS, Liu SH. Effects of caffeine and exercise on the development of bone: a densitometric and histomorphometric study in young wistar rats. Bone 2002; 30(1):293-299.

Jeffcott LB, Henson MD. Studies on growth cartilage in the horse and their application to an etiopathogenesis of dyschondroplasia (osteochondrosis). The Veterinary Journal 1998; 156:177-192.

Julian RJ. Rapid growh probblems: ascite and skeletal deformities in broilers. Poultry Science 1998; 77:1773-1780.

Julian RJ. Patologias ósseas em aves. In: Conferência Apinco 2005 de Ciência e Tecnologia Avícolas; 2005; Santos, São Paulo. Brasil. supl.2, p.107-122.

Junqueira LC, Carneiro J. Histologia básica texto/Atlas. 10 ed. Rio de Janeiro: Editora Guanabara Koogan; 2004.

Kälebo $P$, Strid $K G$. Bone mass determination from microradiographs by computer-assisted videodensitometry. Acta Radiologica 1988a; 29(4):465-472

Kälebo $P$, Strid $K G$. Bone mass determination from microradiographs by computer-assisted videodensitometry. Acta Radiologica 1988b; 29(5):611-618.

Kastl S, Sommer T, Klein P, Hohenberger W, Engelke K. Accuracy and precision of bone mineral density and bone mineral content in excised rat humeri using fan beam dual-energy $\mathrm{x}$-ray absorptiometry. Bone 2002; 30(1):243-246.

Kienholz EW, Turk DE, Sunde ML. et al. Effects of zinc deficiency in the diets of hens. Journal Nutrition 1961; 75:211-221.

Korver DR, Saunders-Blades JL, Nodean KL. Assessing bone mineral density in vivo: quantitative computed tomography. Poultry Science 2004; 83:222-229, 2004.

Landauer W. The hatchability of chicken eggs as influenced by environment and heredity. Storrs, CT: Storrs Agricultural Experiment Station; 1967. (Monograph, 1).

Loubel L, Dubois M. Manual de sensitometria: la técnica de la medición de los materiais fotográficos. 2 ed. Barcelona: Ediciones Omega; 1973. 238p.

Louzada MJQ, Xavier CAM, Marques Neto JF. Ação da calcitonina na resolução de perfurações ósseas em coelhos: controle fotodensitométrico e histológico. Revista Brasileira de Reumatologia 1990; 30(4):111-116. 
Louzada MJQ. Otimização da técnica de densitometria óptica em imagens radiográficas de peças ósseas. Estudo "in Vitro" [tese]. Campinas: Universidade Estadual de Campinas; 1994.

Louzada MJQ. Densidade de peças ósseas de frangos. Estudo pela densitometria óptica radiográfica. Veterinária e Zootecnia 1997; 9: 95-109.

Luquetti BC, Bruno LDG, Giacheto PF, Furlan RL, Gonzales E, Macari $M$. Influência da idade da matriz sobre características da casca e parâmetros sanguíneos e cardíacos de pintos neonatos. In: Conferência Apinco 2002 de Ciência e Tecnologia Avícolas; 2002; Campinas, São Paulo. Brasil. p.5.

Maggioni R. Efeito do fracionamento de cálcio dietético sobre o desempenho produtivo e a qualidade da casca do ovo de poedeiras semi-pesadas durante o verão [dissertação]. Pelotas: Universidade Federal de Pelotas; 1998.

Oliveira MC, Rodrigues EA, Bruno LDG, Marques RH, Gravena RA, Moraes VWB. Características ósseas de frangos de corte alimentados com dietas contendo mananologossacarídeo e complexo enzimático. In: Conferência Apinco 2005 de Ciência e Tecnologia Avícolas; 2005; Santos, São Paulo. Brasil. p.41. Suplemento da Revista Brasileira de Ciência Avícola, Prêmio Lamas 2005.

Onyango EM, Hester PY, Stroshime R. et al. Bone densitometry as am indicator of tíbia ash in broiler chickens fed varying dietary calcium and phosphorus levels. Poultry Science 2003; 82:17871797.

Orban JI, Roland SR, Bryant MM. Factors influencing bone mineral content, density, breaking streng, and ash as response criteria for assessing bone quality in chickens. Poultry Science 1983; 72(3):43756.

Pharr JW, Bargai U. Radiology. In: Greenough PR, Weaver AD, editor. Lameness in cattle. $3^{\text {th }}$ ed. Philadelphia: W.B. Saunders Company; 1997. p.24-40.

Schreiweis MA, Orban JI, Ledur MC. et al. The use densitometry to detect differences in bone mineral density and content of live white Leghorns fed Varying levels of dietary Calcium. Poultry Science 2003, 82:1292-1301.

Seedor JG. The biophosphanate alendronate (MK-217) inhibit bone loss due to ovariectomy in rats. Journal of Bone and Mineral Research 1995; 4:265-270.

Tavano O, Dezotti MSG, Iwaki LCV. Comparação entre a densidade óptica obtida pelo método convencional e densidade radiográfica obtida pelo programa Adobe Photoshop 5.0 em filmes radiográficos Kodak TMS-1. Revista da ABRO 2000; 1(2):07-14.

Thorp $\mathrm{BH}$. Abnormalities in the growth of long bones. Proceedings of the 23 Poultry Science Symposium; 1992; Abington: Carfax; 1992. p.147-166.

Wilson HR, Miller ER, Harms RH, Damron BL. Hatchability of chicken eggs by dietary phosphorus and calcium. Poultry Science 1980; 59: 1284-1289.
Wilson HR, Ingram DR, Harms RH. Restricted feeding of broiler breeders. Poultry Science 1983; 62:1133-1141.

Whithead CC, Fleming RH. Osteoporsis in cage layers. Poultry Science 1999; 78:1033-1041.

Zhang B, Coon CN. The relations ships of various tibia bone measurements in hens. Poultry Science 1997; 76:1698-1701. 


\title{
Vencedores do Prêmio Lamas'2006
}

\author{
SANIDADE \\ Vencedor \\ "Vírus da Bronquite Infecciosa das Galinhas e Pneumovírus Aviário Associado com \\ Problemas de Fertilidade em Galos" - Laura Yaneth Villarreal B.
}

\section{NUTRIÇÃO}

Vencedor

"Efeito de Fontes de Metionina e Níveis de Potássio do Desempenho de Frangos de Corte Submetidos a Condições de Verão Brasileiro" - Andréa Machado Leal Ribeiro - UFRGS - Faculdade de Agronomia - Porto Alegre - RS

Menção Honrosa

“Efeitos de Diferentes Níveis de Energia e Aminoácidos sobre o Desempenho de Frangos de Corte" - Leonardo José Camargos Lara - UFMG - Escola de Veterinária Belo Horizonte - MG

\section{MANEJO}

Vencedor

"Estresse Térmico no Nascedouro sobre a Função Imune de Frangos" - Karoll Andrea Alfonso Torres

Menção Honrosa

"Análise Multivariada para Ocorrências de Comportamentos e Variáveis de Produção de Matrizes Pesadas" - Danilo Florentino Pereira

\section{OUTRAS ÁREAS}

Vencedor

"Rastreabilidade da Farinha de Vísceras na Alimentação de Frangos de Corte por meio da Análise Isotópica de Diferentes Tecidos" - Ricardo Pinto de Oliveira - Unesp - Instituto de Biociências de Botucatu - SP

\section{Menção Honrosa}

"Curvas de Crescimento e da Deposição de Nutrientes Corporais de Duas Linhagens de Frangos de Corte" - Simara Márcia Marcato - Unesp - Faculdade de Ciências Agrárias e Veterinárias - Jaboticabal - SP 